\title{
FRUIT PRODUCTION IN CHILE: BRIGHT PAST, UNCERTAIN FUTURE ${ }^{1}$
}

\author{
JORGE B. RETAMALES² \&JUAN CARLOS SEPÚLVEDA ${ }^{3}$
}

ABSTRACT - In 2007 (the last agricultural census), Chile had 308, 445 ha of fruit orchards: an increase of almost 32\% from the previous census (1997). The most important species were table grapes (20\%), avocados $(13 \%)$ and apples $(12 \%)$. Some $22 \%$ of the fruit crops growing area corresponded to juvenile orchards; within the species with higher proportion of juvenile orchards were prunes $(42 \%)$ and blueberries $(56 \%)$. Most orchards are located between latitude $27^{\circ} 18^{\prime} \mathrm{S}$ (Copiapó) and $40^{\circ} 36^{\prime} \mathrm{S}$ (Puerto Varas). The industry is driven by the export component which accounts for more than $50 \%$ of the fruits produced. In the crop season 2009-2010, approximately 254 million boxes (around 2.5 million tons) were exported, representing over US\$ 3.5 million. Processed and fresh fruits represented 8.2 and $26.7 \%$ of the total forest and agricultural Chilean exports in 2008, respectively. The main markets for this fruits were USA/Canada (42\%) and Europe (32\%). The fruit grower receives, on average, $12-16 \%$ of the total price of the fruit in its final destination. Each year the fruit industry employs 450.000 people directly, of which $1 / 3$ are permanent. Even though the fruit industry employs the highest proportion of the agricultural labor and the growing area has increased in the last 20 years, the proportion of agricultural employment has decreased from $19.5 \%$ in 1989 to $10.8 \%$ in 2008. It might also be noted that Chile invests only $0.7 \%$ of the GDP in research. In the last 40 years, the fruit industry has been a motor for the Chilean economic development, but the lower rates of currency exchange, the rising costs of energy (oil, electricity), and the increasing scarcity of hand labor have drastically reduced the profitability and are putting at risk the viability of a large proportion of the fruit orchards in Chile. It is estimated that this season around $65 \%$ of the orchards will have a negative economic balance in their operations. Higher investment in research, improvements in fruit quality and various orchard management practices, as well as higher financial support from the Government are needed for the long term viability of the fruit industry in Chile.

Index terms: statistics, fruits, exportations.

\section{PRODUÇÃODE FRUTAS NOCHILE: PASSADO BRILHANTE, FUTUROINCERTO}

RESUMO - Em 2007 (último censo agrícola), o Chile tinha 308.445 ha de pomares: um aumento de quase $32 \%$ em relação ao censo anterior (1997). As espécies mais importantes foram, uva de mesa (20\%), abacate (13\%) e maçã (12\%). Cerca de $20 \%$ da terra ocupada pela fruticultura, correspondeu a pomares juvenis; desse total, as espécies com maior proporção de pomares juvenis foram ameixeiras (42\%) e mirtilos (56\%). A maioria dos pomares está localizada entre as latitudes $27^{\circ} 18^{`} \mathrm{~S}$ (Copiapó) e $40^{\circ} 36^{\prime} \mathrm{S}$ (Porto Varas). A fruticultura é impulsionada pela exportação que corresponde a mais de 50\% das frutas produzidas. Na safra 2009-2010, aproximadamente 254 milhões de caixas (cerca de 2.5 milhões de toneladas) foram exportados, representando mais de US\$ 3,5 milhões. Frutas processadas e frescas representaram 8,2 e 26,7\% das exportações chilenas de produtos florestais e agrícolas em 2008, respectivamente. Os principais mercados para essas frutas foram EUA/Canadá (42\%) e Europa (32\%). O fruticultor recebe em média 12-16\% do preço total da fruta em seu destino final. A cada ano a fruticultura emprega diretamente 450.000 de pessoas das quais $1 / 3$ é permanente. Ainda que a fruticultura empregue a maior proporção da mão-de-obra rural, e que a área plantada tenha aumentado nos últimos 20 anos, a proporção dos empregos rurais decresceu de 19,5\% em 1989 a 10,8\% em 2008. Deve ser notado também que o Chile investe somente $0.7 \%$ do GDP em pesquisa. Nos últimos 40 anos, a fruticultura tem sido a força propulsora do desenvolvimento econômico chileno, mas as taxas de câmbio mais baixas, a elevação dos custos de energia (óleo, eletricidade), e a crescente escassez de mão-de-obra têm reduzido drasticamente a rentabilidade e estão pondo em risco a viabilidade de uma grande proporção de pomares no Chile. Estima-se que nesta safra, cerca de $70 \%$ dos pomares apresentarão balanço econômico negativo em suas operações. Maior investimento em pesquisa, aprimoramento da qualidade das frutas e de várias práticas de manejo dos pomares, assim como maior suporte financeiro governamental são requeridos para a viabilidade a longo prazo da fruticultura no Chile.

Termos para indexação: estatísticas,frutas, exportações.

\footnotetext{
${ }^{1}$ Palestra Sinfruit 108 - Simpósio Internacional de Fruticultura - Avanços na Fruticultura (17 a 21 Outubro)

${ }^{2}$ Universidad de Talca and Sociedad Chilena de Fruticultura (SOCHIFRUT).E-mail: jretamal@utalca.cl

${ }^{3}$ Federación de Productores de Fruta (FEDEFRUTA)
} 


\section{INTRODUCTION}

\section{Importance of fruit sector in Chilean economy}

Fruit production in Chile reached 324,293 ha planted (Censo Agropecuario, 2007). It extends between latitudes $27^{\circ} 18^{\prime} \mathrm{S}$ (Copiapó) and $40^{\circ} 36^{\prime} \mathrm{S}$ (Puerto Varas); however, more than $70 \%$ of the orchards are located between latitudes $30^{\circ} 15^{\prime}$ ( $\mathrm{La}$ Serena) and $36^{\circ} 50^{\prime} \mathrm{S}$ (Concepción) (Figure 1). Nearly 16,000 growers participate in the fruit production sector, of which around 7,800 export fruit. There are also 518 exporting companies and more than 60 processors. The sector includes 300 nurseries, 385 cold storage facilities, 100 permanent fruit packing houses and more than 1,000 temporary packing facilities (established in the orchards). The presence of the desert (North), Pacific Ocean (west) and Andes (east), isolate the country from pests. This is exemplified by the absence of Phylloxera (a major grape pest) in Chile.

Fruit export is concentrated in few companies, since 16 of the most important ones represent $50 \%$ of the shipments. Several of the exporting companies have also bought or planted orchards, and even some of them own nurseries. This shows that there is a tendency for a vertical integration of the sector.

The sector provides jobs for 450,000 people $(180,000$ permanent and 270,000 temporary jobs $)$. If the indirect activities are included (transport, ports, clerks, services, etc.), a total of 1.5 million jobs relate to this sector. Even though the fruit industry employs the largest proportion of the agricultural labor and that the area planted has increased in the last 20 years, the proportion of agricultural employment has decreased from $19.5 \%$ in 1989 to $10.8 \%$ in 2008 . The fruit grower receives, on average, $12-16 \%$ of the total price the fruit obtains upon sale in the final destination.

Fruit culture plays an important role in Chilean economy, as in the last decade it has provided 1.07 to $1.46 \%$ of the GNP. However, this proportion can reach $2.6 \%$ if the indirect economical activities linked to fruit export are included. Fruit production represents nearly $40 \%$ of the agricultural gross product.

\section{Surface area and main crops}

The 2007 national census established that the total area planted to fruit crops was 324,293 ha, which meant an expansion of $38.3 \%$ as compared with 1997. Of this total $19.2 \%$ is occupied for table grapes, 12.1 for avocados, and 11.5 for apples (Table
1). Among the new species incorporated in the last 20 years are: hazelnut, blueberries, and olives. From the total of land devoted to fruit crops, nearly $22 \%$ was juvenile. Within this total, the species with the largest proportion of juvenile orchards were prunes $(42 \%)$ and blueberries (56\%) (CENSO AGROPECUARIO, 2007).

\section{Chilean fruit and the world markets}

In the last years, the Chilean fruit sector has shown both growth and diversification, based on fruit exports for the fresh and processed market. This expansion has been a result of the joint effort from the public and private sectors. Now fresh fruit from Chile are reaching directly to 70 countries with more than 70 different species (VIO et al., 2009). According to information from the National Office of Agricultural Policies (ODEPA) and the Chilean Central Bank, the export of Chilean fresh fruit in the year 2008 totalled US\$3,387 million (FOB), which represented a 150\% expansion compared with figures for the year 2000 . In the 2009-2010 season, approximately 254 million boxes (around 2.5 million tons) were exported, representing over US\$ 3.5 million. In the case of processed fruit, the export value of this item in 2008 was US\$ 1,042 million, with a volume of 541,000 tons. The value of fresh and processed fruit amount for nearly $35 \%$ of the total exports of the agricultural sector (Lumber+Animal+Agriculture) (Table 2).

Of the total fruit produced by Chile, nearly $45 \%$ is exported as fresh and $14 \%$ as processed. Figures from 2008 show the following proportions of the total value of fruit exports in descending order according to species: $37.6 \%$ for table grapes, $20 \%$ for apples, $6.4 \%$ for blueberries, $6.2 \%$ for cherries, $5.2 \%$ for kiwifruit and $4.3 \%$ for avocados. When classified as groups of species, the proportions of the total value of exported fruit are the following: grapes $(37.6 \%)$, pome fruit $(24.1 \%)$, stone fruit $(13.6 \%)$, berries $(6.8 \%)$, nuts $(5.2 \%)$, citrus $(2.7 \%)$, other tropical and subtropical (4.3\%).

Within the processed fruit products, the most important components are the dehydrated and frozen fruit, with 31 and $24 \%$ of the value of processed fruit exported in 2008. These were followed by fruit sauces, fruit juices and canned fruit. In the case of dehydrated fruit the volume exported in 2008 reached 123,000 tons and generated a value of US\$ 325 million. The most important product exported were raisins ( $39 \%$ of total), which was exported mainly to Venezuela, Mexico and United States. Another important dehydrated fruit, which has increased markedly in the last 10 years, are prunes with $37 \%$ and 
whose main markets are Mexico, Russia, Germany and Venezuela. A total of 103,000 tons of frozen fruit were exported in 2008. Of this total, raspberries represented $52 \%$ and the main markets for this export were USA, Germany, Canada and France.

Chile actively promotes fresh fruit exports by providing funding for promotional and marketing strategies as well as technical assistance. The funding from growers and exporters is scarce. The primary institution for marketing and export promotion is PROCHILE, which is the Chilean government's export promotion agency. PROCHILE provides export assistance through matching grants, technical assistance, overseas representation, and market information services. PROCHILE administers a $\$ 10$ million Export Promotion Fund, providing matching grants to assist development of new markets and promotion of all nontraditional agricultural products. The Chilean Ministry of Agriculture (MOA) also provides monetary support to promote agricultural exports (PROCHILE is funded through the MOA). Additionally, the MOA provides policy and technical support to assist exporters. Chile has actively sought free trade agreements with trading partners such as the United States, European Union, MERCOSUR, Peru, Colombia, Venezuela, Bolivia, Panama, Mexico, and Canada (USDA, 2006).

\section{Situation of Chilean exports within the Southern hemisphere}

According to the figures from FAO (2006), Chile is the leading export country in fresh fruit exports within the southern hemisphere. In 2008, Chile had $40 \%$ share of the total exported from this region. In descending order, the other important exporters of fresh fruit are South Africa (26\%), Argentina (17\%), and New Zealand (8\%). The relative importance of Chile within the southern hemisphere grew from $6 \%$ in 1961 , to $49 \%$ in 2001 . The highest rate of growth in fruit exports from the southern hemisphere was in the nineties (Table 3).

\section{Main markets for Chilean fruit}

In a global context, in the year 2005 Chile represented $5.1 \%$ of the fruit exported in the world. In that year, the exports of Chilean fruit as related to the southern hemisphere (SH) and the world (W) exports for the main species, had the following rankings: table grapes (1 SH, 1W); apples (1 SH, 4W); plums (1 SH, $1 \mathrm{~W})$; peaches $(1 \mathrm{SH}, 5 \mathrm{~W})$; pears $(1$ $\mathrm{SH}, 6 \mathrm{~W})$; kiwi (2 SH, 2W); avocados (1 SH, 2W); blueberries $(1 \mathrm{SH}, 5 \mathrm{~W})$; raspberries $(1 \mathrm{SH}, 3 \mathrm{~W})$.
In the 2005-2009, the participation of Chile in the world market of fresh fruit has remained stable both in volume as well as in value, fluctuating between 7.5 and $7,9 \%$ of the total world imported volume and between 8,1 and $8,8 \%$ in terms of value. These figures reflect certain stagnation of the Chilean industry in the capture of a greater share of the international markets, considering that these markets have been quite dynamic, especially with regards to the value component (Bravo, 2011).

According to data from 2006-2007 season, the main market in terms of value (US\$) for the fresh fruit exported by Chile was North America (49.3\%), followed by Europe (28\%), Asia (10.4\%), and SouthCentral America (10.2\%). In terms of volume, the main markets for the fruit were USA/Canada (42\%) and Europe (32\%). The importance of North America and Europe has been reinforced in the last 10 years by the Free Trade Agreements between Chile and these economic powers.

In the case of processed fruit, the main destination for Chilean exports in 2006-2007 was USA (19.4\% of total exports), followed by Mexico (10.1\%), and Venezuela $(9.7 \%)$.

\section{Critical points and challenges for the Chilean fruit sector}

According to a study of the National Council for Competitiveness (CNIC, 2007), Chile has the opportunity to reach by 2012 annual exports between US\$ 900 and 1,500 million, based on different analysis scenarios. In order to reach that potential, in the case of fresh fruit, Chile has to develop or strengthen the following critical points:

- Increase the diversity of the markets. This should allow higher prices for the fruit

- Improve the quality of fruit exported to access higher prices

- Increase the productivity through an improvement of the growers and the workers. This will require more research. However, the expenditure in science is low as Chile invests only $0.7 \%$ of its GDP in research

- Incorporate new land into production

In the case of processed foods, the above mentioned study states that Chile should aim to export US\$ 4,300 million in 2017. Fruit and vegetables is the sector with largest size and development in the last years, and with highest potential for the future. To reach this goal, this sector needs to face the following critical points:

- Supply of raw materials (fruit)

- Cost of hand labor and inputs. This cost has in- 
creased $36.4 \%$ in the last 15 years (FEDEFRUTA, 2011).

- Incorporation of small- and medium-size growers In the last 40 years, the fruit industry has been a motor for the Chilean economic development. However, the industry is facing difficulties that have drastically reduced the profitability and are putting at risk the viability of a large proportion of the fruit orchards in Chile. It is estimated that this season around $65 \%$ of the orchards will have a negative economic balance in their operations. The Federation of Chilean Fruit Growers has stated that this is the worst crisis in the last 25 years (Fedefruta, 2011). In this context, the most important challenges that are going to be faced by the Chilean fresh fruit exporting sector are:

Lower rates of currency exchange. In the last ten years, the currency rate has drop 33\% (FEDEFRUTA, 2011).

Rising costs of energy. Oil price in 2010 was four times higher than in 2001, while electricity was
3.1 times higher in 2010 than in 2004.

Greater scarcity and higher cost of hand labor. Labor accounts for $40-70 \%$ of the cost of producing fruit in Chile. In some crops mechanization may allow their production at reasonable cost in the near future. However, since Chile is focused on the export of fresh fruit, mechanical harvesting is generally not compatible with adequate postharvest life and condition of the fruit upon arrival to the markets.

Increase productivity of the industry in certain crops. Precision agriculture and improved irrigation and fertilization, among other practices, should reduce costs and improve sustainability.

Need to homogenize the composition of shipments. Otherwise the perception of quality will decrease among customers.

Increase investment in research and innovation.

Sustainable production practices. The market is increasingly demanding production practices that are friendly with the environment. The growers are aware of this and are advancing in various ways.

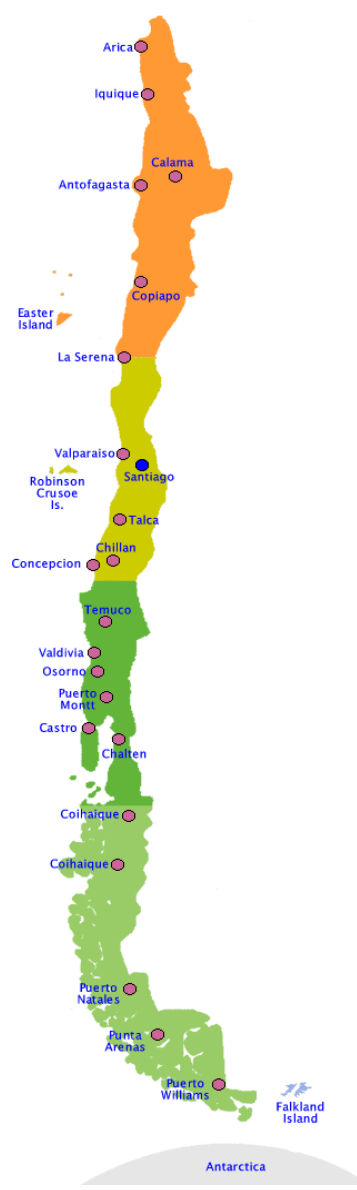

FIGURE 1 - Geographical map of Chile. Main fruit growing in Chile (marked in yellow) extends from La Serena (Lat. $30^{\circ} 15^{\prime} \mathrm{S}$ ) to Concepción (Lat. $36^{\circ} 50^{\prime} \mathrm{S}$ ). 
TABLE 1 - Area planted to fruit orchards in Chile (juvenile and production) in 2007.

\begin{tabular}{lccc}
\hline \multicolumn{1}{c}{ Crops } & Juvenile (ha) & Production (ha) & Total (ha) \\
\hline Table grapes & 9.326 & 53.085 & 62.411 \\
Avocado & 8.411 & 30.892 & 39.303 \\
Apple & 4.421 & 31.614 & 36.035 \\
Olive & 6.858 & 9.662 & 16.520 \\
Walnut & 5.218 & 9.366 & 14.584 \\
Cherry & 4.283 & 9.157 & 13.440 \\
Prunes & 5.087 & 7.016 & 12.103 \\
Blueberry & 5.995 & 4.768 & 10.763 \\
Peach (canning) & 1.327 & 8.951 & 10.278 \\
Kiwi & 3.072 & 6.877 & 9.949 \\
Orange & 1.788 & 7.443 & 9.231 \\
Lemon & 872 & 6.984 & 7.856 \\
Almond & 2.163 & 5.553 & 7.716 \\
Others & 10.538 & 61.766 & 72.304 \\
Total & $\mathbf{6 9 . 3 5 9}$ & $\mathbf{2 5 3 . 1 3 4}$ & $\mathbf{3 2 4 . 2 9 3}$ \\
\hline
\end{tabular}

Source: Censo agropecuario, 2007

TABLE 2 - Participation of fresh and processed fruit in Chilean agricultural (Lumber+Animal+Agriculture: LAA), for years 2000, 2005 and 2008. Source: Vio et al., 2009.

\begin{tabular}{|l|c|c|c|}
\hline Item & 2000 & 2005 & 2008 \\
\hline Total LAA & 4,977 & 8,044 & 12,697 \\
\hline Fresh fruit: FF & 1,351 & 2,151 & 3,387 \\
\hline Proportion FF/LAA (\%) & 27.1 & 26.7 & 26.7 \\
\hline Processed fruit: PF & 293 & 630 & 1,042 \\
\hline Proportion PF/LAA (\%) & 5.9 & 7.1 & 8.2 \\
\hline
\end{tabular}

TABLE 3 - Evolution from 1961 to 2001 of the proportion exported by Chile as part of the total fresh fruit exported by the Southern Hemisphere (SH). Source: FAO, 2005.

\begin{tabular}{|l|c|c|c|c|c|}
\hline Item & 1961 & 1970 & 1980 & 1990 & 2001 \\
\hline Chilean exports (\%) & 6 & 25 & 45 & 47 & 49 \\
\hline Other countries in SH (\%) & 9 & 75 & 55 & 53 & 51 \\
\hline Growth SH (\%) & -- & 50 & 54 & 204 & 62 \\
\hline Volume SH (M boxes) & 469 & 704 & 1,083 & 2,204 & 3,569 \\
\hline
\end{tabular}

\section{CONCLUSIONS}

The expansion of the Chilean fruit industry was initiated in the sixties, and by 2007 Chile had 324,293 ha of fruit orchards. The most important species are table grapes (20\%), avocados (13\%) and apples $(12 \%)$. Greater than $67 \%$ of the orchards are located between latitudes $30^{\circ} 15^{\prime}$ (Coquimbo) and $36^{\circ}$ 11'35" S (Parral). The main focus of the Chilean fruit industry is the export of fresh fruit. Chile is number one exporter within the southern hemisphere, and in a global context is the largest exporter of table grapes and plums. The main markets for this fruit are USA/ Canada (42\%) and Europe (32\%). Each year the fruit industry provides nearly 450.000 jobs, of which $1 / 3$ are permanent. Since the sixties, the fruit industry has been a major actor in Chilean economic development, but several problems have markedly reduced the profitability of this sector: lower rates of currency exchange, rising costs of energy (oil, electricity), and greater scarcity and cost of hand labor. This situation is putting at risk the future of a large proportion of the 
fruit industry. Chile needs greater efficiency and for this more research is needed; however, the country invests little in science ( $0.7 \%$ of the GDP). To change this situation and maintain the viability of the Chilean fruit industry, long term governmental policies, greater investment in research, improvements in fruit quality, and various changes in orchard management practices are needed.

\section{REFERENCES}

BRAVO, J. EI mercado de fruta fresca 2010. Disponível em: <www.odepa.cl/odepaweb/publicaciones/ doc/2474.pdf>. Acesso em: 12 jul. 2011.

CENSO AGROPECUARIO. 2007. Disponivel em: $<$ www.censoagropecuario.cl/index $2 . h t m l>$. Acesso em: 23 jun. 2011.

CNIC - Consejo Nacional de Innovación para la competitividad. 2007. Disponivel em: <www. cnic.cl/media/users/3/181868/.../Agenda_Innovacion_2010-2020.pdf $>$. Acesso em: 12 jul. 2011.
FAO. Agricultural statistics. 2005. Disponível em: <www.faostat.fao.org/site/567/DesktopDefault. aspx?PageID=567\#ancor $>$. Acesso em: 23 jun. 2011.

FEDEFRUTA. EI sector enfrenta su peor crisis de rentabilidad de los últimos 25 años. 2011. Disponível em: $<$ www.fedefruta.cl/?area=Noticias\&id=939 $>$. Acesso em: 12 jul. 2011

USDA. The World fresh fruit market. 2006. Disponível em: <www.fas.usda.gov/htp/Hort_Circular/2006/02-06/World $\% 20$ Fresh $\% 20$ Fruit $\% 20$ Market\%202004.pdf>. Acesso em: 13 jul. 2011.

VIO, M.,. ETCHEGARAY, M.J.; IOANNIDIS, D.; FERREIRA, Y I. Formación de capacidades humanas en biotecnología aplicable a la fruticultura en Chile: diagnóstico. Santiago de Chile: CONACYT, 2009. $266 \mathrm{p}$. 